\title{
Linkages to Public Land Framework: toward embedding humans in ecosystem analyses by using "inside-out social assessment"
}

\author{
JoAnNa ENDTER-WAdA ${ }^{1,2,4}$ AND DALE J. BLAHNA ${ }^{3}$ \\ ${ }^{1}$ Department of Environment and Society, Utah State University, Logan, Utah 84322-5215 USA \\ ${ }^{2}$ Ecology Center, Utah State University, Logan, Utah 84322-5205 USA \\ ${ }^{3}$ USDA Forest Service, Pacific Northwest Research Station, 400 NW 34th, Suite 201, Seattle, Washington 98103 USA
}

\begin{abstract}
This article presents the "Linkages to Public Land" (LPL) Framework, a general but comprehensive data-gathering and analysis approach aimed at informing citizen and agency decision making about the social environment of public land. This social assessment and planning approach identifies and categorizes various types of linkages that people have to public land and guides the tasks of finding and using information on people in those linkages. Linkages are defined as the "coupling mechanisms" that explain how and why humans interact with ecosystems, while linkage analyses are empirical investigations contextualized both temporally and geographically. The conceptual, legal, and theoretical underpinnings of five basic linkage categories (tribal, use, interest, neighboring land, and decision making) and further refinement into subcategories are explained. These categories are based upon the complex property and decision-making regimes governing public land. Applying an "inside-out" analytic perspective, the LPL Framework assesses the social environment inside public land units and traces linkages out into the larger social environment, instead of assessing the outside social environment (communities or stakeholders) and assuming linkages exist between the social entities and public lands, as is generally done in social assessments. The LPL Framework can be utilized in management activities such as assessing baseline conditions and designing monitoring protocols, planning and evaluating management alternatives, analyzing impacts of decisions, structuring public involvement and conflict management efforts, and conducting collaborative learning and stewardship activities. The framework enhances understanding of human dimensions of ecosystem management by providing a conceptual map of human linkages to public land and a stepwise process for focusing and contextualizing social analyses. The framework facilitates analysis of the compatibilities, conflicts, and trade-offs between various linkages, and between cumulative human linkages and capabilities of public land to sustain them. While the LPL Framework was developed for use in planning for U.S. National Forests, it could be applied to other types of public land in the United States and adapted and extended to public lands and common property areas in other countries.
\end{abstract}

Key words: common property; coupled natural-human systems; forest policy; human dimensions of ecosystem management; public involvement; public land access; social impact assessment.

\section{INTRODUCTION}

Over the past two decades, ecosystem management has emerged as a dominant paradigm guiding public land and resource management in the United States (U.S.). Distinguishing dimensions of this paradigm include: managing for ecological integrity and sustainability; addressing problems at large ecosystem scales that may encompass land, aquatic, and marine environments; promoting institutional and public processes that are collaborative and adaptive; coordinating across landownership and jurisdictional and institutional boundaries; and incorporating human dimensions com-

Manuscript received 15 December 2010; revised 31 May 2011; accepted 3 June 2011; final version received 8 July 2011. Corresponding Editor: R. L. Knight.

${ }^{4}$ E-mail: Joanna.Endter-Wada@usu.edu ponents (Grumbine 1994, Thomas 1994, Yaffee et al. 1996, Kohm and Franklin 1997, McDonnell and Pickett 1997, Cortner and Moote 1999, Wondolleck and Yaffee 2000, Meffe et al. 2002, Keiter 2003, Breen 2008, Layzer 2008, McLeod and Leslie 2009).

Assessments of the effectiveness of an ecosystem approach to management have yielded mixed results (Yaffee et al. 1996, Butler and Koontz 2005, Keough and Blahna 2006, Doyle and Drew 2008, Layzer 2008). Expanding the scales of analyses has improved ecological understandings of ecosystems (e.g., Waring and Running 2007, Hobbs and Suding 2009, Coleman 2010), while experiences with collaboration and adaptive management have aided formulation of practical guidelines for interacting with the public and responding to changing realities (Wondolleck and Yaffee 2000, Meffe et al. 2002, McKinney and Harmon 2004, Armitage et al. 2008, Allan and Stankey 2009). Most observers agree 
that the approach has proved effective in many situations, but admit that its benefits as an environmental management strategy have yet to be fully realized, especially in terms of the overriding goal to integrate ecological and human dimensions of ecosystems. Mixed assessment results are not surprising given the variety and complexity of the contexts in which ecosystem management has been employed, the short time frame for implementation relative to the magnitude of problems that took much longer to emerge, and variations in evaluation criteria that can be applied to an approach with many dimensions.

Case studies of ecosystem management reveal that human aspects remain the most problematic dimension of this new paradigm (Keough and Blahna 2006, Breen 2008, Doyle and Drew 2008, Layzer 2008, Fretwell 2009, Nie 2009). We think this is partially due to the fact that ecosystem science remains primarily defined as biophysical in nature (cf., Sala et al. 2000, Young and Giese 2003, H. John Heinz III Center for Science, Economics and the Environment 2008, Thorpe et al. 2008, Coleman 2010). Integrating humans into ecosystem management largely focuses on improving public involvement in planning, policy, and other decision-making processes and is less concerned with incorporating humans into the science of understanding ecosystems of which humans are important components (Endter-Wada et al. 1998). The interface of ecosystem science and policy can be particularly contentious when human aspects of ecosystems are not dealt with in a systematic, analytic, and reflective manner.

While ecosystem management approaches recognize that humans are an integral part of natural systems, this is not easily turned into practical analyses and guidelines for resource managers and needs more systematic conceptualization and articulation (Butler and Koontz 2005). Approaches and tools are needed for investigating the "full spectrum of relevant linkages between the social and biophysical realms" and "to address the variability in those linkages across the full spectrum of relevant communities" (Endter-Wada et al. 1998:895). Understanding linkages between people and resources, and interdependencies between people linked to resources in different ways, can be critical elements in people's choices of whether to pursue conflict or cooperation in relation to natural resource and environmental issues (Ostrom 1990, 2005, Endter-Wada et al. 2009).

The goal of truly integrating humans in ecosystem management is especially difficult for public land management agencies in the United States. Social assessment and analysis designed to support agency comprehensive land management plans is fraught with conceptual and methodological problems. One of the most significant limitations is the inability to focus social analyses on the most relevant planning issues, and understanding the direct connection between human social groups and communities and the resources being considered has been repeatedly criticized in litigation, in public involvement activities, and in the literature (Blahna and Yonts-Shepard 1989, Bardwell 1991, Lachapelle et al. 2003, Clark and Stankey 2006). Land management agencies are adept at conducting and using biological research, and doing on-site analysis of uses and resources, but linking resource uses and conditions to relevant social groups and communities off site is problematic. Yet, without those explicit linkages, the applicability of agency social analyses is unclear at best, and potentially meaningless.

This paper presents the Linkages to Public Land Framework (LPL Framework) for doing the social assessment and analysis necessary for understanding the human dimensions of ecosystem science and management. We first discuss social analysis needs in ecosystem management and key weaknesses of current approaches. Then we describe the LPL Framework and provide application guidelines and several examples. Conceptually, we argue that social assessments should identify the forms of actual use or access to public lands or decisionmaking processes and trace linkages to social groups outside public land boundaries ("inside out" social assessment), rather than start with social communities or groups in the abstract (e.g., loggers or a community), and then assume linkages exist. We aim to demonstrate the usefulness of the LPL Framework as a methodological tool that can help resource managers assess resource access and linkage issues to evaluate a range of social effects from agency to project-level policies and decisions for various types of human groups. While our primary contribution is innovation in social impact assessment methodology, the framework also can be used to structure public involvement, to further understanding of coupled natural-human systems, and to aid progress towards embedding humans in ecosystem analyses. The framework was developed for use in planning for U.S. National Forests, but could be applied to other types of public land in the United States and adapted and extended to public lands and common property areas in other countries.

\section{Social Analysis Needs in Ecosystem Management}

It is now widely accepted that successful planning and decision making for land management depends upon the integration of social, economic, and ecological factors (FEMAT 1993, Endter-Wada and Lilieholm 1995, Committee of Scientists 1999, Moran and Ostrom 2005, Donoghue and Sturtevant 2008). Social factors are the least researched and least often applied of the three criteria, yet social and political concerns often delay or halt projects regardless of potential ecological or economic benefits (Gilmore 1997, Layzer 2008). The two primary approaches for collecting social information for ecosystem management are social assessment (or social analysis) and public involvement. Social assessment differs from public involvement in that its purpose is to collect more scientific, systematic, and representative data related to human dimensions of public land 
planning and management (Endter-Wada et al. 1998, IOCGP 2003, Taylor et al. 2004). While public involvement can generate data that are useful in social assessments, the information is targeted and related to specific issues and stakeholders.

In the past, most social assessments conducted to support public land planning and ecosystem management projects tended to be of two kinds: "visitor use" studies and assessments of the characteristics of human communities and stakeholder groups. Visitor studies primarily deal with on-site actions of recreationists and focus on relatively narrow issues and questions of human behavior, preferences, or attitudes. This problem has been partially addressed in recent years through the use of place attachment studies that analyze deeper meanings and symbolic uses of public lands by visitor or stakeholder groups (Williams et al. 1992, Eisenhauer et al. 2000, Davenport and Anderson 2005, Kruger et al. 2008). These studies provide important insights for addressing specific issues, landscapes, or management needs, but they are time and data intensive, so they are rarely applied on a large-scale, systematic, or ongoing basis.

Community-based studies, on the other hand, focus on off-site social factors primarily through socioeconomic assessments of communities located in a project's "zone of influence." Traditionally, these studies included social and economic data from secondary sources (e.g., U.S. Census and related reports organized by political boundaries), and they were sometimes supplemented with attitude data from social surveys (Gray et al. 2001, Meffe et al. 2002, Kusel and Adler 2003, Donoghue and Sturtevant 2007, 2008). The goal is to provide an understanding of the extent to which communities are dependent on public lands and how changes in public land management and policy would impact community well-being. A problem with these approaches, however, is that it is often unclear how secondary measures of community structure and well-being actually reflect public land policies or management activities. In a review of the experience of social scientists on the Forest Ecosystem Management Team (FEMAT 1993), an early attempt to link large-scale ecosystem management practices and community socioeconomic conditions, McLain et al. (2008:722) found that even linking forestry jobs and timber harvest levels was problematic:

Some researchers suggested that levels of timber harvest, number of jobs, and the estimated value of spin-off economic activities were adequate proxies for community well-being, with high levels of harvest implicitly linked with high levels of well-being. Others disagreed, arguing that harvest levels and the value of related economic activities are neither clearly nor causally linked to community well-being.

Since FEMAT, using secondary social indicators alone has been recognized as static, and not representing the dynamic nature of social systems (Berkes et al. 2003,
Tsournos and Haynes 2004, McLain et al. 2008). Several new approaches based on concepts of community social capital were developed in an effort to understand community capacity, resilience, and vulnerability (cf., Doak and Kusel 1996, Harris et al. 1998, 2000, Kusel 2001, 2003, Flora et al. 2004, Charnley 2006, Donoghue and Sturtevant 2007, 2008). These measures provided a significant improvement in our understanding of the theoretical relationship between ecosystem management and rural community well-being and adaptability to change, but they are still based on secondary indicators of community conditions. Thus, the linkage between these indicators and specific public land management practices and policies remains implicit. In a review of lessons learned from socioeconomic assessments for five large-scale ecosystem management projects, McLain and her colleagues (2008:722), which included three scientists who developed measures of community wellbeing and adaptability (Charnley, Kusel, and Donoghue), concluded: "Researchers have made less progress in clarifying the relationship between socioeconomic conditions and ecosystem management policies." Yet discussions of the limitations of existing social assessment measures focus almost entirely on improving the community indicators themselves, such as incorporating subjective measures of "sense of place," and not on methods for linking them to actual public land use and agency policies (cf., Kusel 2001, 2003, McLain et al. 2008).

The problem of linking social conditions directly to resources has been partially addressed through studies of "communities of interest" (FEMAT 1993, Brandenburg and Carroll 1995). Also called stakeholder analyses, these studies focus analysis on groups of people that have similar interests (e.g., occupational or recreational groups) related to public land management, even though they may not live in the same geographic community. It has now become common to include stakeholder groups in ecosystem social assessments, but there can be many hundreds of such groups or subgroups depending on the scale or purpose of the assessment. Like on-site place attachment studies, these analyses are more directly linked to the land, but they tend to be data intensive, and issue or landscape specific, as well as time bound; as a result, they are rarely collected or monitored by agency staff over time (Blahna et al. 2003).

Another persistent problem with traditional social assessments is that they tend to measure specific points in time with little or no follow up to monitor trends or test outcomes of policy or management changes (Geisler 1993). Many analysts (cf., Bliss et al. 2001, McLain et al. 2008) cite time and budget constraints that exist because monitoring socioeconomic conditions is undervalued compared to monitoring physical and ecological conditions. The ultimate cause of this marginalization of social assessment, however, may be that the relevance of social assessment is 
unclear when the data are not directly linked to public land and ecosystem management policies and practices.

A final persistent problem with traditional social assessment is uncertainty about the appropriate unit of analysis or zone of influence for conducting analysis (Blahna et al. 2003, Kusel 2003). Social systems, like ecological systems, are "nested," and there is no clear and unambiguous assessment unit or boundary (Beckley 1998). Ecosystem management is a very general concept, wherein many resource use, conservation, and preservation values may be at odds with one another. Without specific issues or guidelines to bound a social analysis, social values such as local jobs, regional biodiversity, and national preservation may all have very different social zones of influence, and different issues would require different levels and scales of analysis (Blahna et al. 2003).

The policy and management focus of ecosystem management is on long-term and integrated resource conservation programs designed to meet objectives related to forest health and social and resource sustainability (Boyce and Haney 1997, Committee of Scientists 1999, Young and Giese 2003, Norton 2005, Breen 2008, Doyle and Drew 2008, Hobbs and Suding 2009). This focus requires management strategies that often have complex and unpredictable social effects. Resource conservation programs are often modified from their original design as agencies respond to change, which means the hypothetical programs studied in preproject phases are different from actual programs at various stages of implementation (Geisler 1993). To be integrated with biophysical data, social science information must be directly linked to the physical environment of public lands. This integration also requires a relevant zone of influence and data that are consistently collected and updated over time. If these criteria are not met, social data are difficult to use in conjunction with physical and ecological data in adaptive management strategies designed to deal with coupled natural and human systems (Geisler 1993, Berkes et al. 2003, Holling 2005, Stankey et al. 2005, Liu et al. 2007a, b).

\section{A New Approach to Embed Humans in Ecosystem Analyses}

We argue that social assessment will remain a secondary concern for ecosystem analyses and will not be adequately used in resource planning and management until agencies can see the direct relevance of such data and develop appropriate guidelines and practices for data collection and utilization. To help meet these needs, the Linkages to Public Land Framework provides a general but comprehensive conceptual framework and assessment tool for describing and monitoring human linkages that are important for public land planning and decision making, and for applying social analysis methods to specific land management areas and issues. The framework is based on a synthesis of the property rights, access, and institutional analysis literatures, but focuses on practical realities of public land use policy, planning, and management. The approach characterizes human linkages relevant to public land in the United States, taking into account the political, legal, and institutional history governing that land (Wilkinson 1992, Keiter 2003, Pierson 2004). Our objectives are to improve the use of social science to inform public land policy and management, further the use of existing agency data sets to understand linkages between people and public lands, and focus and prioritize analysts' efforts on the nature of natural-human ecosystem couplings.

We developed and refined the LPL Framework over the past seven years through consultations with three National Forests in Utah regarding forest plan revisions and through discussions with participants in short courses delivered to U.S. Forest Service staff called Continuing Education for Ecosystem Management (conducted through Utah State University, Logan, Utah; Colorado State University, Ft. Collins, Colorado; and Northern Arizona University, Flagstaff, Arizona, USA). Many U.S. Forest Service staff members told us that they had not effectively used social and economic data in the past. The main reasons given were that these data were not directly linked to lands they managed or to agency decision-making authorities and they often had trouble understanding the relevance of more generalized social and economic data about surrounding communities and counties. Agency staff expressed the need for a different approach to social assessment, although they had trouble articulating specifically what that would be. They wanted people to better understand the U.S. Forest Services' legal and policy environment and related management dilemmas, the public to be able to "see themselves" in agency assessments, and agency staff to be able to use assessments as tools for communicating with the public.

We also found that every national forest in the United States has a large number of databases at its disposal, many of which include information on people who are linked to the national forests in various ways. But the potential social data from these sources often are not used effectively in forest planning or decision documents. For example, every year, U.S. Forest Service staff writes thousands of permits and contracts specifying the nature of access and resource use on the national forests. Information gathered through these procedures is typically used only to describe aggregate annual changes in uses on national forest lands. However, many of these documents contain useful information on the permitees or contractors, including their addresses, how long their approvals have been in effect, the legal basis and regulations guiding their activities, the amount of the relevant resources that may be obtained, conditions or specifications on use, and geographic location of the approved activities. Thus, permit and contract data can be used to describe the nature of linkages to public land, as well as to characterize people in those linkages, and to 
trace linkages from locations on national forests to places where people reside (Endter-Wada and Blahna 2004, Lilieholm et al. 2008, Mekbeb et al. 2009).

In addition to permit and contract data, many other types of information already collected by U.S. Forest Service staff can be used to help understand human linkages to public land. Examples include campsite fee slips, wilderness access registers, and public meeting and law enforcement records. Currently, most of this information is kept in the U.S. Forest Service corporate database as administrative records, but it is rarely treated as social assessment data. There are several reasons for this. For one, the data need to be standardized (e.g., by community population) to provide generalizable social science information about community dependency or adaptability (Utah GOPB 2003, Lilieholm et al. 2008, Mekbeb et al. 2009). Also, the quality of social information collected by agencies can be uneven, and may not adequately describe both ends of the public land linkages (i.e., location on the forest and location of place outside the forest to which that linkage extends). And, until recently, most of the public linkage data on the national forests have been collected in different departments and stored in non-relational databases. In fact, many of these data were not stored electronically at all, and hard copies were simply thrown away after a period of time. In recent years, however, the data access and management capabilities of the U.S. Forest Service have expanded tremendously, increasing potential use of previously underutilized agency corporate data.

To develop the linkages framework, we interviewed U.S. Forest Service and state resource agency staff, identified candidate data sources, evaluated relevant data files for information regarding human linkages, reviewed various types of documentation (forms, permits, agreements, meeting notes) that help define the nature of human linkages to public land, and identified human linkage variables potentially available but not yet recorded or stored in electronic format. The data we found for assessing people's linkages to public land were of two types: (1) information on nature of the linkages (i.e., legal and financial aspects of the linkages, stewardship responsibilities, type of interest, etc.), and (2) information on people in the linkages and locations and resources to which they are linked. Our search for information of the second type focused on key elements of the "linkages" concept; that is, we focused on databases that contain, or could potentially contain (since data availability and quality varied by forest) information on the name and address of forest user group, their activity and its location on the forest, and stipulations of resource use. The primary U.S. Forest Service databases we used to develop the framework were: Timber Information Manager; volunteer report forms; National Visitor Use Monitoring (NVUM) surveys; public meeting and scoping records; public correspondence files; newspaper clipping archives; and several INFRA (an integrated suite of Forest Service software applications and databases) modules related to engineered infrastructure (dams, roads, waste systems, and water systems) and range, recreation, timber, visitor, wilderness, and special use linkages.

In the rest of this paper, we primarily describe the Linkages to Public Land Framework and provide guidelines for and illustrations of its application. This presentation is largely conceptual and illustrative; more details and examples may be found in the report we coproduced with the Utah Governor's Office of Planning and Budget to support the forest plan revision process for the Dixie, Fishlake, and Manti-La Sal National Forests (Utah GOPB 2003).

\section{Linkages to Public Land Framework}

"Linkages to Public Land" is a framework that embeds humans in ecosystem analyses by providing a general conceptual map of human linkages to public land and a stepwise process for focusing and contextualizing analyses of these linkages. Its "inside-out" methodological approach to social assessment provides general guidelines for comprehensive data gathering and analysis aimed at informing citizen and agency decision making about the social environment of public land. The framework facilitates theory development in ecosystem science and public land policy by focusing attention on variables relevant for understanding structural properties and dynamic processes of coupled natural-human systems within the context of property and decision-making regimes governing public land in the United States.

In this section, we: (1) define linkages that constitute the principle units of analysis in this framework; (2) explain the conceptual and theoretical foundations for the approach; (3) present the LPL Framework, identifying, and defining major categories of linkages relevant to public land; (4) provide guidelines for applying the framework; and (5) illustrate linkage analysis with several application examples.

\section{Linkages as units of analysis}

The LPL Framework focuses on linkages that people have to public land and guides the tasks of finding and using information on people in those linkages. Linkages are defined as the "coupling mechanisms" that explain how and why humans interact with landscapes or ecosystems in contexts that are defined both temporally and geographically (Fig. 1). These coupling mechanisms shape direct and indirect connections to land and resources, as well as access to and influence over decision-making processes about that land and those resources. Coupling mechanisms are affected by the physical characteristics of public land and its resources and become specified through historical circumstances and trajectories that result in people having different types of linkages to public land, varying abilities to benefit from those linkages, and a range of vulnerabilities to land management changes. With regard to public land in the United States, these coupling mechanisms are highly influenced by policies, laws, rules and regulations of 


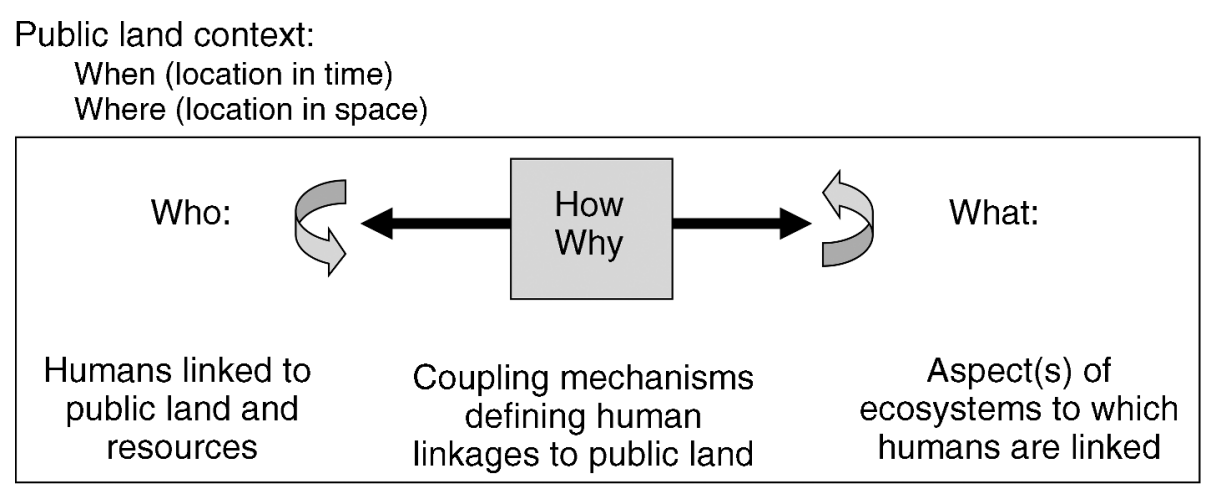

FIG. 1. Illustration of elements of linkages to public land analysis focused on understanding coupled human-natural systems.

the institutions governing public land management, but also are shaped by informal or unauthorized linkages and political struggles over access to public land. Thus, the LPL Framework focuses, first and foremost, on the nature of relationships people have to public land and to decisionmaking processes about it (linkages) and then, secondarily, on the entities (e.g., individuals, groups, or communities) that may be in those linkages and the resources (e.g., rangeland, water, or recreational sites) to which they are linked.

\section{Conceptual and theoretical foundations of the approach}

Integrating human dimensions into ecosystem science and management is based on the premises that humans be viewed as part of ecosystems (not outside them) and that social science dimensions be analytically equal to biophysical dimensions (Endter-Wada et al. 1998, Gunderson and Holling 2001, Berkes et al. 2003). Thus, the conceptual focus of the LPL Framework is on analyzing people within the geographical context of public land to better understand coupled natural-human systems in public land settings.

Standard social assessment approaches, in essence, attempt to trace connections between people and public land from the "outside in" to public land units, utilizing data about proximate communities and identified stakeholders assumed to be resource dependent and assumed to form a "zone of influence." In other words, the linkage direction for standard social analysis starts from communities or social groups external to the public land unit (e.g., national forest) and linkages to public land and resources are generally hypothesized rather than empirically measured. But for social information to be pertinent to public land decision making, documentation is needed of direct connections between people and the lands and resources for which an agency is responsible. The LPL Framework, on the other hand, uses "inside out social assessment," starting with connection points on the public land unit and tracing linkages out into the larger social environment (Fig. 2). In the LPL Framework, the basic units of analysis are linkages, and not communities or social groups. Thus, the LPL Framework avoids the assumptions that people are mainly linked to public land through place of residence, their interest or occupational community, or proximity to public lands. In addition, the zone of influence is not fixed, but depends on the geographic extent of actual linkages.

Theoretical foundations of the framework are based on insights provided by scholars contributing to our understanding of the complex and dynamic policy and institutional mechanisms within which U.S. public land and, more generally, common property is managed. These mechanisms are the key to understanding the coupling of natural and human systems in U.S. public land contexts. The rich U.S. public land policy and law literature reveals that public land management in the United States is rife with conflicts rooted in historical struggles over property claims, tensions between government policies of disposal and retention of the public domain, and resulting contradictions between mandates and expectations regarding use, protection, and preservation. Existing human linkages to public land are the legacy of an accumulation of laws and past decisions and actions regarding ownership, allocation, and use of land and resources that are now contained in public land units (Clawson and Held 1957, Gates 1968, 1979, Dana and Fairfax 1980, Wilkinson 1992, Hanna et al. 1996, Fairfax et al. 1999, 2005, Freyfogle 2003, 2007, Leigh 2003, McKinney and Harmon 2004, Coggins et al. 2007).

Contextualized analyses have shown that public land and resource management regimes can be highly complex and contentious, and rights to public resources often include conflicting informal claims (Fortmann 1990, Ribot and Peluso 2003, Selfa and Endter-Wada 2008). Fortmann (1990) documents how non-aboriginal customary usufructuary rights to National Forest System lands in the United States can be a source of rural protest and action, forming the basis of claims to continue local residents' access to national forest firewood in the face of legal claims that would reduce their access (e.g., redirecting wood to a proposed woodfired power plant). Ribot and Peluso's (2003) theory of access indicates informal or "structural and institutional" mechanisms (e.g., available technology, knowledge, 
Traditional social assessment: traces connections "in" to public land units

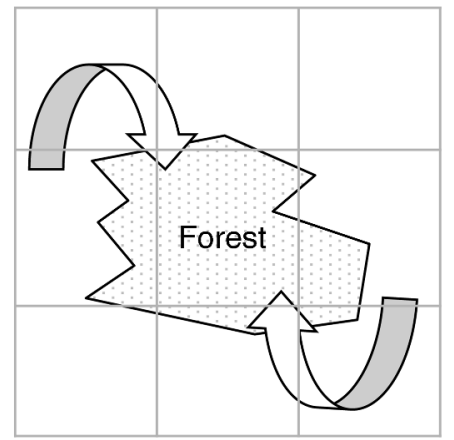

Surrounding counties and nearby communities are assumed to form the public land unit's (e.g. forest's) zone of influence.
LPL Framework: traces linkages "out" from public land units

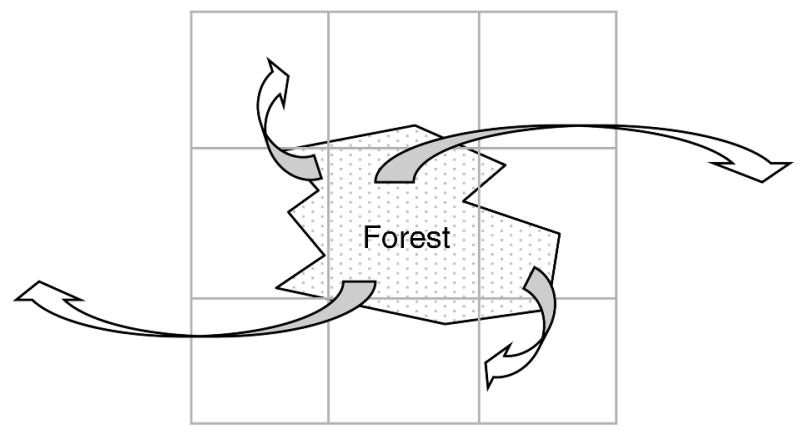

A zone of influence is identified for each linkage category by tracing linkages to surrounding areas and beyond.

FIG. 2. Comparison of traditional Social Impact Assessment (SIA) and Linkages to Public Land (LPL) Framework approaches for describing the social environments of public land.

social relations) also define access to land and resources (2003:164-172), and these means, relations, and processes of access give people the power or ability to derive benefits from resources (2003:158-159).

Fairfax et al. critique "[t]he conventional wisdom, symbolized on maps depicting large solid blocks of federal lands. . that the federal lands are relatively uninterrupted areas of federal ownership and jurisdiction, where federal agencies make decisions about management" (1999:633). They base their argument on diverse claims of ownership characteristic of public land (intermixed ownership, leases, private development, access rights, informal claims), split administrative jurisdiction (institutional evolution, receipt sharing, regulatory authority), and rights for the public to participate in decision making and management. They advocate that "the existing allocation rules must be properly understood" (1999:630), noting that "[t]he lands encoded 'federal' on maps are in fact a tapestry of public and private rights and entitlements and a landscape of ecological interactions" (1999:646). These policy analysts also note that legally established expectations of public involvement (such as those established under the Administrative Procedures Act, the National Environmental Policy Act, or the National Forest Management Act) have reduced the role of federal managers and have severely compromised the ability of resource agencies to unilaterally set program priorities.

Schneider and Ingram's theory of policy design describes how "policy designs are produced through a dynamic historical process involving the social constructions of knowledge and identities of target populations, power relations, and institutions" (1997:5). Societal contexts and issue contexts give rise to policies that are framed, designed, and translated to distribute benefits and burdens to various target populations (Schneider and Ingram 1997). Applied to public land management, their theory helps to explain contentions rooted in the dynamics of a changing policy context as various groups and entities seek to obtain and formalize access and use rights to public land and resources. Through the many treaties, statutes, rules, policies, and permits governing management of public land and resources, multiple uses have been authorized and various users have been given rights, opportunities, privileges, and permissions, as well as responsibilities, to utilize public land and resources and to be involved in decision making at various levels (as specified in U.S. Forest Service handbooks, manuals, and directives). Formal laws and policies define both the legal and illegal uses of lands and resources (Schneider and Ingram 1997, Ribot and Peluso 2003).

Ostrom and Schlager $(1992,1996)$ discuss five basic rights that are held by users of a public resource or common property system: access, withdrawal (or extraction), management, exclusion, and alienation (or transferability). Access is the right to enter a defined physical area, use the land and resources in place, and enjoy non-subtractive benefits (i.e., one person's use does not subtract from another person's potential use). Examples of the right of access are hiking, canoeing, and sitting in the sun. Withdrawal (or extraction) is the right to obtain the resource units or "products" of a resource, examples of which are catching fish, appropriating water, gathering firewood, collecting seeds, or harvesting timber. Management is the right to regulate the internal use patterns and transform the resource by making improvements, i.e., it is the authority to determine how, when, and where harvesting a resource may occur, and whether and how the structure of a resource may be changed. Examples of management are ranchers adding structures to restrict cattle movement or a university operating an experimental forest. Exclusion is the right to determine who will have 
TABLE 1. Combinations of basic rights associated with different positions (or use linkages) to resources.

\begin{tabular}{lccccc}
\hline \hline \multirow{2}{*}{\multicolumn{1}{c}{ Positions }} & \multicolumn{5}{c}{ Rights } \\
\cline { 2 - 6 } \multicolumn{1}{c}{ Access } & Withdrawal & Management & Exclusion & Alienation \\
\hline Authorized entrant & $\mathrm{X}$ & $\mathrm{X}$ & & & \\
Authorized user & $\mathrm{X}$ & $\mathrm{X}$ & $\mathrm{X}$ & & \\
Claimant & $\mathrm{X}$ & $\mathrm{X}$ & $\mathrm{X}$ & $\mathrm{X}$ & \\
Proprietor & $\mathrm{X}$ & $\mathrm{X}$ & $\mathrm{X}$ & $\mathrm{X}$ & $\mathrm{X}$ \\
Owner & $\mathrm{X}$ & $\mathrm{X}$ & &
\end{tabular}

Note: The table is based on Ostrom and Schlager (1992).

access (i.e., it is the authority to define the qualifications individuals must meet in order to access a resource) and how those rights may be transferred. Examples of the right to exclude other people relate to ski resorts, summer homes, and hydropower facilities. Alienation (or transferability) is the right to sell or lease some or all of the previous rights, such as water rights or mineral rights. Ostrom and Schlager (1992) note that some of these rights are entailed in others, and bundles of these rights are associated with different positions vis-à-vis public or common property resources. In their illustration, positions with increasing resource rights are labeled authorized entrant, authorized user, claimant, proprietor, and owner (see Table 1).

The LPL Framework recognizes and assesses people's rights, privileges, and expectations related to public land which the U.S. Forest Service and other resource agencies are obliged to enforce and which they must balance with legal mandates and obligations to "the resource." We draw upon these various conceptual and theoretical insights in defining use linkages and applying them to public land in the United States.

\section{Presentation of the LPL Framework}

In the LPL Framework, linkages to public land are defined by the nature of relationships between people and public land. This approach recognizes that there are fundamental distinctions between different ways people are linked to public land and resources that affect how they may benefit or be burdened by land management decisions and actions (including policies, plans, programs, and projects subject to National Environmental Policy Act [NEPA] analyses). In this way, the framework attempts to clarify the nature of the "stake" that people often referred to as "stakeholders" have in public land. Linkages are not defined by the entities that may be in those linkages; thus, particular individuals or entities can have more than one linkage to public land. Neither are linkages necessarily defined by the natural resource(s) to which people are linked, such as water, range, timber, minerals, wildlife, fish, trails, or campsites; thus, people linked to different resources but in similar ways might be analytically equal. The approach is essentially a reorientation of the normal way U.S. land management agencies analyze people and issues.
The LPL Framework recognizes five basic categories of linkages: tribal linkages, use linkages, neighboring land linkages, interest linkages, and decision-making linkages. Designed as a general, comprehensive set of mutually exclusive categories, the framework guides analysis toward types of linkages between people and public land that exist in policy, law, and practice. Some linkages are more readily analyzed than others because they have greater visibility, documentation, official sanction, or social legitimacy, often due to prescribed administrative procedures or the power of people in those linkages. Some linkages will be pertinent to a particular area or issue, while others will not. Deciding which linkages are relevant and analyzing how they are actually forged is the task of empirical social analysis.

What follows are brief descriptions of the framework's linkage categories, which are listed in the LPL assessment tool in Fig. 3.

Tribal linkages.-These linkages refer to the relationships and special connections that have developed over generations between Native Americans and the lands they inhabited and resources they used. Besides their historic precedence, these linkages recognize treaty rights that sovereign nations of Native Americans negotiated with the United States to use certain resources now contained on public land. Tribal linkages are defined by a combination of treaty rights, federally protected uses reserved for Native Americans, government-to-government relationships between tribes and federal and state governments, and trust responsibilities of the federal government to Native American tribes. Various federal laws require recognition of tribal "prerogatives," such as: Archaeological Resources Protection Act, American Indian Religious Freedom Act, Religious Freedom Restoration Act, Native American Graves Protection and Repatriation Act, National Historic Preservation Act, and Executive Order Number 13007 on Indian Sacred Sites. Tribal linkages are a separate category because of their unique status under U.S. law and because they simultaneously define both the "uses" (related to historic practices) and the "users" (members of tribal groups, native peoples). These linkages are established both from the "inside out" as well as the "outside in" through decision processes 


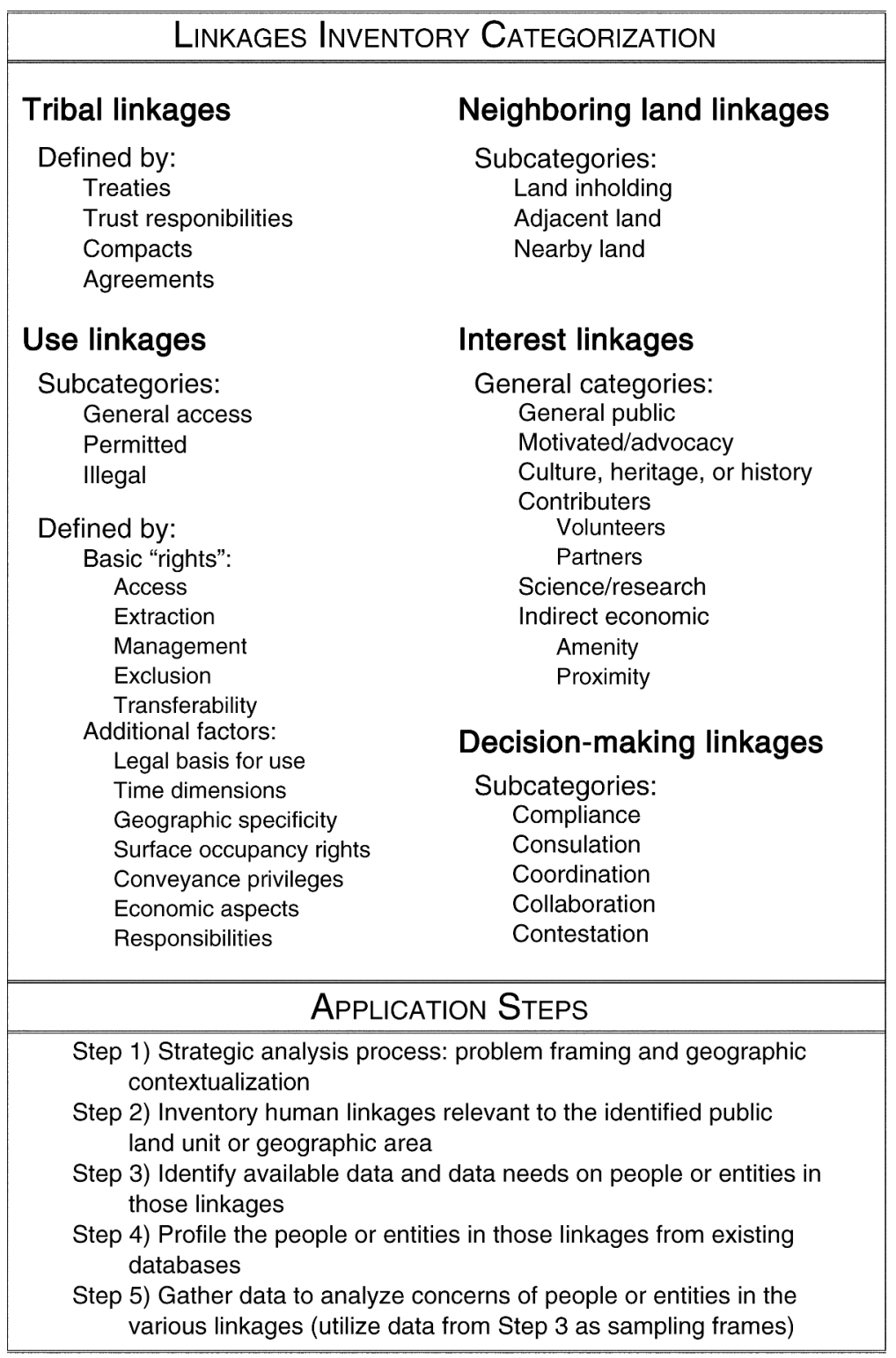

FIG. 3. Linkages to Public Land (LPL) assessment tool summarizing basic linkage categories and application steps.

about native peoples' rights outside the U.S. Forest Service administrative authorities.

Use linkages.-These linkages generally refer to established uses of land and resources and imply a physical connection to public land. Some of these uses constitute the existing legal agreements between the government and users that define people's rights, privileges, and responsibilities to use public land through contracts, leases, and permits. Other of these uses may emanate from customary and usufructuary rights or claims or from acts of civil disobedience. These uses can be changed or enforced as conditions warrant, but such changes entail legal implications, social impacts, or stewardship opportunities that agencies may need or want to take into account in their decision making.

The many types of use linkages are organized into three subcategories: (1) general-access uses, which are authorized uses that do not require users to obtain formal documented permission but may, nonetheless, entail general rules of use; (2) permitted uses, which are legally authorized uses, but require specific users to obtain documented permission (e.g., contracts, leases or permits) granting them the right to use the resource in a stipulated way; and (3) illegal uses, which are uses that are either expressly forbidden or not authorized, require a permit that the user has not obtained, or are appropriately permitted, but the conditions of the permit have been violated. 
Of all the LPL categories, use linkages most directly reflect the policies and laws that establish public rights and expectations to access and use public land resources as identified in the public land policy, resource access, and political ecology literatures: i.e., people's rights or powers to access, extract, and manage resources, exclude other people from using the resource, and/or transfer (sell) their rights and responsibilities (see Table 1). Thus, for instance, within permitted uses, "authorized users" of many different types of resources (e.g., wood, seeds, fish, and wildlife) are categorized as being in the same type of use linkage if they share the same basic rights of "access" and "withdrawal." On the other hand, people who hold mineral rights, water rights, or occupancy rights for cell phone towers may be categorized and analyzed as having the same type of use linkage if they share the general rights of access and withdrawal but also "management" (of an area or structure), "exclusion" (ability to keep others away from their operations), and "alienation" (ability to sell their rights to others, subject to the terms and conditions of use).

Additional stipulations help analysts to define, characterize, and evaluate the nature of linkages. These stipulations are often contained in management plans or in permits, agreements, and contracts between resource agencies and users and help to identify the expectations that managers or parties to the agreement have about the relevant use. For example, with permitted uses, these stipulations often include legal bases for the use of public land, time dimensions associated with use, geographic specificity of the use, surface occupancy and conveyance privileges, means of engaging in the activity, and economic aspects associated with use (e.g., whether the user has contracted or paid a fee for the right to use public land).

For instance, U.S. Forest Service forest product removal permits for personal harvesting activities, such as firewood or Christmas tree cutting, specify the manner in which people are allowed to engage in those activities, and may include stipulations like what trees can be harvested and where and how they can be cut, how the product may be transported, what is owed for the quantity of product removed, and other rules to be followed (see form FS-2400-2401, BLM-5450-24, OMB Number 0596-0085, expires 31 January 2012).

For another example, U.S. Forest Service special use permits for noncommercial group use do the following: establish legal authority for the use; define the activity, location, number of participants, starting and ending dates and times, and conditions of use; include plans or specifications for how the activity will be conducted; specify responsibilities, liabilities, and conditions for permit expiration, suspension, or revocation; and record information on and a signature from the person obtaining the permit on behalf of the group (see form FS-2700-2703b(03/05), OMB Number 0596-0082).

Taking these permit considerations into account through explicit descriptions of the documented use rights and allocation agreements can help to inform management decisions, especially in situations that involve conflicts between different uses or different users and that may change future access or extraction potential. While many uses are actually permitted, other uses remain open to the general public ("general-access uses") or occur in an illegal or unauthorized manner. However, documenting these use linkages is rare. The U.S. Forest Service uses permits to produce product summaries rather than using the documents' data as a social analysis tool. It leaves illegal or unauthorized uses to law enforcement personnel, and focuses management on those general-access uses it feels are not well managed (e.g., dispersed camping) or environmentally sensitive (e.g., wilderness access). A more complete understanding of the social environment of public land requires analysis of all three subcategories of use linkages, especially as these uses relate to one another and to the broader social environment of the forest, since this is often the source of public land and resource conflicts.

Neighboring land linkages.-These linkages to public land are through ownership or management of land within, adjacent to, or nearby public land units. Ownership or management may be by private entities (e.g., individuals, corporations, nonprofit entities) or the land may be held by local, state, or federal governments. Mutual obligations of neighboring landowners have deep roots in property law and land use planning (Ellickson 1991). Neighboring land linkages are particularly important in the context of identifying management issues or broad socioeconomic trends that may affect both public and private land.

Three basic subcategories of neighboring land are identified in recognition of the fact that owners and managers of various types of neighboring land are linked to public land in different ways, depending on geographical proximity and location of their land in relation to public land. The three subcategories of neighboring land linkages are: (1) inholding linkages, where an owner's land is completely within a public land unit so that access must be through public land; (2) adjacent land linkages, where an owner's land shares a property boundary but is not entirely within a public land unit; and (3) nearby land linkages, where an owner's land is not directly within or adjacent to public land, but situated in the same watershed or airshed, or along the same transportation corridor, in a way that makes it likely to be directly affected (through benefits or burdens) by actions on public land or, alternatively, to affect public land through actions occurring on it.

Interest linkages.-In the United States, these linkages to public land come through people being part owners (by being U.S. citizens) or having other identified interests that give them a say in decisions about how public land should be managed (e.g., scientists or other land owners concerned about the spread of certain forest diseases). Interest linkages were codified with the 
passage of the Administrative Procedures Act (1946), which requires procedures for government accountability and protects the public's right to be involved in agency decision making. Key subsequent laws in this regard related to public land and resource management include the National Environmental Policy Act, or NEPA (1969), the National Forest Management Act (1976), and the Federal Land Policy and Management Act (1976).

Interest linkages do not necessarily involve a physical connection to public land. People in these linkages may be physically linked to public land in connection with their interest but, in those instances, they would be categorized as being in another linkage in addition to being in an interest linkage (e.g., a use or neighboring land linkage). So, for example, a cattle rancher with a grazing allotment on public land would be included in the use linkage category, but also included as part of the rancher interest linkage along with other ranchers who may want to be involved in a decision for nonpublic land use-related reasons such as aesthetics, implications for property values, or future potential for grazing cattle on public lands. While there may be many subcategories of interest linkages, some general categories of interest linkages include: the general public; "motivated" or "advocacy" interests; cultural, heritage, or historic connections; contributors (e.g., volunteers); scientific interests; and economic linkages not related directly through resource extraction, but indirectly through amenity and proximity interests in neighboring communities.

Decision-making linkages.-These linkages to public land are through institutional jurisdiction, formal arrangements for joint decision or management responsibility of public land or resources, or actions for contesting land management agencies' decisions with other decisions, such as going to court. Generally, government officials and agencies as well as other land management organizations are in decision-making linkages, but these linkages also include actors in decision-making situations that identifiably link them to particular public land units or places. In the United States, decision-making linkages often result from the fact that authority and responsibility over managing resources, implementing laws, and overseeing permitting processes have been divided between different levels of government (federal, tribe, state, and local), different branches of government (legislature, executive, and judiciary), and different agencies within those governments. These linkages also include entities involved with joint or comanagement agreements such as private land trusts and experimental forests collaborations. Recognizing that other government agencies and the public have varying levels of influence and authority over decisions made by agencies and entities charged with managing public land, five subcategories of decision-making linkages are identified: compliance linkages, consultation linkages, coordination linkages, collaboration linkages, and contestation linkages. These subcategories of decision-making linkages are defined as follows.
Compliance linkages.-These linkages consist of instances where oversight of compliance with various laws is assigned to another government agency and, in order to comply with these laws, a resource agency must go through formal permitting or permission procedures handled by another agency. Examples are the need for the U.S. Forest Service to comply with air and water quality laws administered by the Environmental Protection Agency and various states' departments of environmental quality, and with the Endangered Species Act (ESA) implemented by the U.S. Fish and Wildlife Service in relation to land and freshwater species.

Consultation linkages.-Examples of consultations required of the U.S. Forest Service include consultation with Native American tribes, obtaining formal consistency reviews from states on management plans and actions, and consultation with states' historic preservation officers.

Coordination linkages.-These linkages involve cases where other government agencies have been given joint or primary authority to manage various natural resources found on public land. The nature of these linkages between the public land agency and other agencies is one of coordination and cooperation for effective land planning and management, even though it may not be legally mandated. Examples of coordination linkages are management by state agencies of the wildlife, water, and minerals found on public land.

Collaboration linkages.-These linkages entail active collaborations that exhibit some power sharing in decisions or management implementation. These collaborations are in contrast to "traditional" public involvement, which tends to keep forest managers and the public separate and to be more passive by focusing primarily on providing opportunities for dialogue that may have little or no direct influence on decisions or management implementation (Arnstein 1969, Walker and Daniels 1996). They are also distinguished as unique by the Public Participation Spectrum of the International Association for Public Participation (2007; available online). ${ }^{5}$ Collaboration linkages would be covered by formally documented agreements or memoranda of understanding (MOUs) that include shared responsibilities over resource decisions. Common examples for land management agencies in the United States include range management cooperatives, watershed councils, and restoration or stewardship partnerships.

Contestation linkages.-These linkages include circumstances where agency policies, plans, projects, or other actions are contested using confrontational means, either legal or illegal, aimed at stopping or slowing their implementation. These linkages may include formal appeals and litigation (as allowed by the National Forest Management Act and other legislation), legal protest, and symbolic actions like petitions or demonstrations,

\footnotetext{
5 /http://www.iap2.org/associations/4748/files/ IAP2\%20Spectrum_vertical.pdf $\rangle$
} 
or illegal actions like barricading roads, "tree-sitting," and bombing agency facilities.

\section{Guidelines for applying the LPL Framework}

In presenting the LPL Framework to U.S. Forest Service staff and short course participants, we developed a series of recommended steps for investigating linkages to the land in a planning or decision-making process (bottom of Fig. 3). While this list is not exhaustive, it was designed to provide sample application guidance and illustrates that the LPL Framework can be usefully applied in a variety of stages from problem framing to monitoring the social environment.

The first step in using the LPL Framework is to help with the strategic analysis process of problem framing and contextualization. Problem framing is a critical but often ignored first step in any management decision or planning process (Senge 1990, Bardwell 1991, March 1994, Lachapelle et al. 2003). Clark and Stankey (2006:17) refer to "problem framing" as "getting the context and question right before actions are taken." This includes focusing on central issues, understanding the decision context, identifying potential hidden assumptions or preconceptions, and surfacing alternative approaches (Blahna and Yonts-Shepard 1989, Williams 2006). A key element of problem framing is seeking to "understand the situation from various perspectives" (Williams and Blahna 2007:75) and to identify the geographic and temporal contexts to which they pertain. The LPL Framework can be an essential tool for a firststage, systematic, coarse-filter assessment of relevant social factors for any ecosystem management problem. All categories in Fig. 3 will not be relevant for all issues, but the framework can aid the analyst with a first-cut identification of the most relevant linkages. There are potentially unlimited ways to frame ecosystem management problems, and having a comprehensive inventory of human linkages can help contextualize that framing; that is, it can provide a preliminary assessment, or a triage function, to help surface relevant issues and social analysis needs, and help reduce the potential for analysis paralysis that accompanies many ecosystem management efforts in land management agencies today.

After identifying the issue-focused and place-based nature of an ecosystem management problem, subsequent steps in applying the LPL Framework lead to greater detail as needed in order to understand the social environment in question. The second step for applying the LPL Framework is to inventory specific human linkages relevant to the public land unit or geographic area under question, using the linkages inventory categorization as a guide (Fig. 3). Closer examination of the nature of these linkages can reveal how people in those linkages relate to public land, and how the various linkages relate to each other. For instance, analysis of specific agreements or permit conditions that structure or shape the relevant linkages people have in a location (e.g., legal obligations, people's positions vis-à-vis resources as in Table 1, timing of use and other considerations) provides a basic understanding of dimensions of the social environment in that place.

The third step is to identify data on people or entities in those linkages. This step helps planners to find appropriate data sources for further analysis of the identified linkages. Public land agency personnel are encouraged to identify internal agency information and to think unconventionally about how it can help describe the social environment of public land and provide information on people linked to it. In particular, agency personnel should consider how administrative paperwork and records (e.g., permit forms, fee collection records, user registers, public meeting and scoping records, law enforcement records) can be utilized as social science data. The main purpose of step three is to establish and document linkages starting with the direct connection to public land (as in the right-hand side of Fig. 2).

The fourth step in applying the LPL Framework is to profile the people or entities in the relevant linkages, in part using data sources identified in step three. Often, general but useful characterizations can be summarized from these existing data sources, such as relative numbers of people or entities in these linkages, where they reside or are located, basic demographic information (e.g., gender can often be inferred from names), and so on. The important part of step four is that linkages to public land established in step three are then traced outside that land unit to establish an actual zone of influence, which likely will vary based on linkage type and characteristics.

Finally, step five is to analyze concerns of people or entities in the various linkages by conducting primary research through surveys, interviews, focus groups, or collaborative learning processes. Databases on people in the various linkages identified in the third step can be used as sampling frames for drawing representative or stratified samples of people to include in this research. This step is recommended as a last step after issues and geographic areas of concern have been identified, linkages have been inventoried and relevant ones identified, existing data sources have been located and utilized, and people in relevant linkages have been profiled. Primary research can be time consuming and costly and would benefit from insights gained in the previous four steps to increase its focus and utility.

Used strategically in this way, the LPL Framework assists analysts to take a comprehensive look at human linkages (Steps 1 and 2) and then to focus their analyses (Steps 3-5) according to decision-making needs.

\section{LPL application illustrations}

This section provides a few brief illustrations of linkage analyses conducted for the Dixie, Fishlake, and Manti-La Sal National Forests in Southern Utah (Utah GOPB 2003). 
The first example illustrates the analytic advantage offered by the LPL Framework's approach of tracing linkages "out" from public land units compared to traditional approaches that attempt to trace connections "in" to public land units. Traditional social and economic assessments tend to be spatially arbitrary and not easily disaggregated to local areas. As a result, it is difficult to distinguish how changes in land management could differentially affect specific communities or groups. Tracing connections for specific sectors of the socioeconomic environment "in" to particular public land units is especially problematic in areas where multiple government agencies manage similar economic activities on distinct but geographically close public land units. This is the case in Southern Utah, for example, where nearly $80 \%$ of the study area for the Dixie, Fishlake, and Manti-La Sal National Forests is in various federal or state land units (Utah GOPB 2003:73), many of which are managed for recreation, tourism, grazing, forest product harvesting, and mineral production.

Using the LPL Framework to trace linkages "out" can help overcome some of the constraints of traditional socioeconomic analyses. Our permit analysis and profiling of people linked to national forests in Southern Utah provided insights into the differential dependencies of various communities defined by commercial as well as nonmarket activities. For instance, the Fishlake National Forest had relatively few total grazing permits $(n=$ 348) at that time, but these were notable for their importance to certain very small, local, agricultural communities like Greenwich, which had four national forest grazing permits in a town of only 67 residents. Outfitter and guide permits for the Manti-La Sal National Forest showed that of 63 total permits, 25 $(40 \%)$ were from three specific nearby communities (Moab with 13, Monticello with 9, and Blanding with 3), while the other permit holders were spread throughout Utah, Arizona, Colorado, Illinois, and California, and no other city or town had more than one permit holder. An analysis of wood products permits from Dixie National Forest permit data showed its highly localized and personal use nature, with only $319(6 \%)$ out of the 4946 permitees being from outside Utah (mostly from adjoining states and none from outside the United States), and with the greatest number of permits (4629 out of 4946 , or $\sim 94 \%$ ) being for personal use. Standardizing the data by population size for each community revealed a cluster of nearby communities where a relatively large percentage of residents harvest (and presumably depend) on wood products from the Dixie National Forest. In the case of firewood permits, for instance, such analysis provides direct use linkage information for actions such as harvest restrictions, road closures, and changes in permit access and use levels.

The second example relates to how the LPL Framework reduces the problem of determining the relevant zone of social analysis, which is often an arbitrary decision in social assessments (e.g., select towns, adjacent counties, the state, a region, or the nation) and can lead to conflicts related to raising the concerns of some communities or groups over others (e.g., local vs. national concerns). There is no single zone of analysis for the LPL Framework; the analysis zone is determined by the geographic dispersion of actual people in the resource linkage categories. For instance, in contrast to the highly localized nature of people linked to national forests in Southern Utah through grazing, outfitter and guide operations, and wood harvesting, holders of many other types of permits (such as for wilderness use, special uses, recreational residences, special events, mineral development, and management of utility and telecommunications sites) were much more dispersed throughout Utah, the United States, and the world. For another instance, our analysis of interest linkages from the forests' mailing lists, submitted public comments, and notes from public meetings revealed that agencies, organizations, and individuals expressing interests through traditional public involvement activities were concentrated in Utah and neighboring states for some resource issues, but were widely dispersed geographically in terms of other resource issues. Furthermore, people's identified interests were categorically distinct in terms of the nature of the interests that linked them to the physical environments or agency decision making and policies concerning southern Utah forests. The interests expressed included (1) general philosophies on forest management, (2) positions on the public processes to be utilized in agency decision making, (3) advocacy for particular uses or users, (4) views on special designations for particular areas, (5) recommendations on the types of analyses or management actions the U.S. Forest Service should undertake, (6) comments about specific improvements to make in particular locations, and (7) compliments or criticisms of the job being done by the agency.

The third example illustrates the utility of following the recommended steps in applying the LPL Framework in order to analyze relevant linkages. With the problem framed as forest plan revision (Step 1) and interest linkages inventoried as one category of linkages relevant to these forests (Step 2), we sought to identify available data on people or entities in interest linkages (Step 3) and to profile them from existing (secondary) databases (Step 4). To supplement the internal agency sources on interest linkages mentioned in the previous paragraph, we analyzed Internet sites that discussed the Dixie, Fishlake, and Manti-La Sal National Forests. Interests identified through our analysis of Internet sites ranged from groups trying to connect with people to engage in various activities together on the forests to groups advocating various political agendas and management scenarios for the forests. Our profiling of the groups revealed several prominent categories of special interests with documented linkages to those forests: (1) wilderness and preservation advocates interested in preserving the 
forests and managing for biodiversity, habitat, watershed and aquatic protection; (2) tourism, travel, outfitter, sporting, and photographer entities with economic interests attached to forest access or, at least, related to proximity to the forests for their amenity values; (3) real estate agencies handling private land sales and having an economic stake in preserving the amenity values in communities near the forests to attract buyers; (4) off-highway vehicle advocates wanting greater access to the forests or more regulated access so that trails did not become overcrowded; (5) scientific groups interested in long-term research on the forests to gain greater understanding of those forest ecosystems; and (6) multiple-use advocate groups interested in use of forests for extractive purposes and wanting to reduce restrictions or limitations due to environmental legislation or pressure from environmental groups. The wealth and detail of the information contained on these Internet sites helped define, from people's own points of view, the nature of their interest linkages, the locations and resources to which their interests were linked, and the policies or decisions that affected their linkages and that they, therefore, were trying to influence.

Such applications of the LPL Framework are useful in trying to understand how various linkages differentially affect people, groups, or communities. They also provide important insights into how specific forest management practices or policy changes will impact people linked to public land, and reveal specific implications for public involvement and social impact mitigation in ways that standard social analysis methods cannot. This approach also assures that, from a social scientific point of view, all linkages to the land are considered in the analysis whether or not they are voiced in public involvement processes.

\section{Discussion And Conclusions}

The primary thesis of this paper is that standard social analyses conducted by public land management agencies seldom provide relevant information about direct linkages between people and public land and, consequently, cannot adequately characterize, analyze, or monitor the social environment of public land for the purposes of ecosystem science and management. Standard social assessments that collect data related to community characteristics like occupation, income, and education, which serve as the basis for community wellbeing and adaptability analyses, only describe social groups or community conditions but say little about actual linkages to public land and provide little direct implications for public land management, policy, planning, or decision making. We argue the LPL Framework can provide the basis for better understanding these linkages, lead to greater recognition and analysis of people as embedded components of ecosystems, and aid in integrating biophysical and human dimensions of ecosystem science and management.
The LPL Framework is first and foremost a methodological approach and analytic tool intended for use in assessing baseline conditions, analyzing social impacts, and planning and devising management alternatives regarding the human dimensions of ecosystems. The framework identifies, defines, categorizes, and guides analyses of the various types of linkages that people have to public land. It is intended to increase the usefulness of social information for public land and resource decision making by providing a comprehensive set of mutually exclusive categories describing how and why people are linked to public land. The LPL Framework helps organize a social scientific analysis of the human dimensions of ecosystem science that is based on existing activities and agreements and, in some cases, existing data. The LPL Framework can also help analysts generate human linkage inventories comparable to biophysical resource inventories, evaluate more completely the range of impacts and opportunities that people/entities are likely to encounter based upon the nature of their linkages, and contribute to more comprehensive analyses of natural-human coupling mechanisms at an ecosystem scale.

The LPL Framework can also guide agencies to devise approaches and protocols for monitoring human linkages to public land or common property over time. Its benefit in this regard would come primarily from evaluating the usefulness of information sources on linkages for providing monitoring information, modifying or revising some of the information gathered and contained in these information sources, and deciding how to more effectively utilize these information sources for monitoring purposes. For example, U.S. Forest Service permit data can be very useful for monitoring people's uses of forest land, but these data must be kept, tracked, and analyzed consistently in order to usefully monitor social change over time. Currently, these data are used to describe on-site uses (e.g., how many cords of firewood are cut on a forest district), but are rarely used to help understand the people or communities who cut and use the wood. Yet this is the essence of a social analysis that has a direct linkage to public lands. In our review of permit files, we found that relatively few changes will need to be made to permit forms in order to obtain information that will be useful for analyses of human dimensions of ecosystems and long-term monitoring relevant to public land management.

In addition to its utility for scientific analyses and for developing planning, management, monitoring strategies, we think the LPL Framework can be used to help structure public involvement, conflict management, and collaboration activities. The framework could help agency staff and the public to visualize the multiple and cumulative linkages to public land, to better understand the difficulties and conflicts involved in agency management decisions, and to develop, exercise, and build public land stewardship capacity at individual, community, and larger public levels. Similarly, portraying various linkages to public land in agency planning 
documents and NEPA analyses is important for enabling people to see their own linkages to specific areas of public land in relationship to other people's linkages to those same areas. This is particularly important in situations where people cannot meet faceto-face in collaborative public involvement sessions to work through conflicts and negotiate solutions. Perhaps such a perspective could lead to a new meaning for "community" in public land contexts by helping people see themselves as a community connected to public land that is broader than stakeholder groups, but more bounded and identifiable and more directly linked to public land than geographic or interest communities. The LPL Framework deals with different linkages to the same pieces of public land, which focuses on shared connections and practical, place-based approaches, instead of describing people based upon their external memberships in dispersed territorial, occupational, or interest communities that often compete in political arenas outside the public land unit on more philosophically based grounds.

Defining and assessing the social environment of public land for ecosystem science and management requires systematic analysis of the various types of linkages people have to public land resources and of how policy or management actions affect those linkages. Documented analysis of linkages to public land can enhance understanding of the inherently difficult task that resource agencies confront in trying to manage the multiple linkages that people have to public land resources. Understanding the full mosaic of linkages can help citizens and public land managers assess the compatibilities, conflicts, and tradeoffs between various linkages, and between all human linkages and capabilities of public land to sustain them.

\section{ACKNOWLEDGMENTS}

The authors developed the ideas presented in this paper as part of research conducted through the Natural Resource and Environmental Policy Program at Utah State University for the Utah Governor's Office of Planning and Budget (Utah GOPB) and the U.S. Forest Service in 2002-2003. The research was part of a forest plan revision process undertaken by the Dixie, Fishlake, and Manti-La Sal National Forests in southern Utah. Additional detail can be found in the GOPB report (available online). ${ }^{6}$ The Linkages to Public Land Framework has been presented annually since 2003 to U.S. Forest Service personnel through the professional training program "Continuing Education in Ecosystem Management." An early version of this paper was presented at the "Elements of Policy-Making, Planning, and Management" session of the Ninth International Symposium for Society and Resource Management (ISSRM) held in Keystone, Colorado, in 2004. The authors thank the following people: U.S. Forest Service personnel involved in this project, particularly Tony Erba, Mary Erickson, Frank Fay, Ann King, Elaine Zieroth, and Kathy La Plante; staff from GOPB, particularly Wes Curtis, Mark Bedel, Michael Hansen, Sharen Hauri, and Kort Utley; from Utah State University, colleagues Judith Kurtzman, James Long, and Theresa Selfa, graduate students Robert Morris and Robert Peterson, and the NSF Advance Program; Louise Fortmann for helpful com-

\footnotetext{
${ }^{6}\langle$ http://www.planning.utah.gov/usfs.htm $\rangle$
}

ments on a draft of the paper; and insightful reviewers. This project was supported, in part, by the Utah Agricultural Experiment Station and the U.S. Forest Service, PNW Research Station.

\section{Literature Cited}

Allan, C., and G. H. Stankey. 2009. Adaptive environmental management: a practitioner's guide. Springer-Verlag, New York, New York, USA.

Armitage, D., F. Berkes, and N. Doubleday, editors. 2008. Adaptive co-management: collaboration, learning, and multilevel governance. University of British Columbia Press, Vancouver, British Columbia, Canada.

Arnstein, S. R. 1969. A ladder of citizen participation. Journal of the American Planning Association 35:216-224.

Bardwell, L. 1991. Problem-framing: A perspective on environmental problem-solving. Environmental Management 15:603-612.

Beckley, T. M. 1998. The nestedness of forest dependence: a conceptual framework and empirical exploration. Society and Natural Resources 11:101-120.

Berkes, F., J. Colding, and C. Folke. 2003. Navigating socialecological systems: building resilience for complexity and change. Cambridge University Press, Cambridge, UK.

Blahna, D. J., D. Carr, and P. Jakes. 2003. Using social community as a measurement unit in conservation planning and ecosystem management. Pages $59-80$ in L. E. Kruger, editor. Understanding community-forest relations. General Technical Report PNW-GTR-566. Pacific Northwest Research Station, USDA Forest Service, Portland, Oregon, USA.

Blahna, D. J., and S. Yonts-Shepard. 1989. "Public involvement in resource planning: toward bridging the gap between policy and implementation." Society and Natural Resources 2:209-227.

Bliss, J., G. Aplet, C. Hartzell, P. Harwood, P. Jahnige, D. Kittredge, S. Lewandowski, and M. L. Soscia. 2001. Community-based ecosystem management. Pages 143-168 in G. J. Gray, M. J. Enzer, and J. Kusel, editors. Understanding community-based forest ecosystem management. Forest Products Press as imprint of Haworth Press, Binghamton, New York, USA.

Boyce, M. S., and A. Haney, editors. 1997. Ecosystem management: applications for sustainable forest and wildlife resources. Yale University Press, New Haven, Connecticut, USA.

Brandenburg, A. M., and M. S. Carroll. 1995. Your place or mine? The effect of place creation on environmental values and landscape meanings. Society and Natural Resources 8:381-398.

Breen, R. E. 2008. Approaching ecosystem management: change and challenge in Forest Service planning in the U.S. Forest Service. VDM Verlag, Saarbrücken, Germany.

Butler, K. F., and T. M. Koontz. 2005. Theory into practice: implementing ecosystem management objectives in the USDA Forest Service. Environmental Management 35:138150.

Charnley, S., technical coordinator. 2006. Northwest forest plan: the first 10 years (1994-2003). Socioeconomic monitoring results. [6 volumes]. General Technical Report PNWGTR-649. Pacific Northwest Research Station, USDA Forest Service, Portland, Oregon, USA.

Clark, R. N., and G. H. Stankey. 2006. Integrated research in natural resources: the key role of problem framing. General Technical Report PNW-GTR-678. Pacific Northwest Research Station, USDA Forest Service, Portland, Oregon, USA. 
Clawson, M., and B. Held. 1957. The federal lands: their use and management. Johns Hopkins University Press, Baltimore, Maryland, USA.

Coggins, G. C., C. F. Wilkinson, J. D. Leshy, and R. L. Fischman. 2007. Federal public land and resources law. Sixth edition. Foundation Press, New York, New York, USA.

Coleman, D. C. 2010. Big ecology: the emergence of ecosystem science. University of California Press, Berkeley, California, USA.

Committee of Scientists. 1999. Sustaining the people's lands: recommendations for stewardship of the national forests and grasslands into the next century. USDA, Washington, D.C., USA.

Cortner, H. J., and M. A. Moote. 1999. The politics of ecosystem management. Island Press, Washington, D.C., USA.

Dana, S. T., and S. K. Fairfax. 1980. Forest and range policy: its development in the United States. McGraw-Hill, New York, New York, USA.

Davenport, M. E., and D. H. Anderson. 2005. Getting from sense of place to place-based management: an interpretive investigation of place meanings and perceptions of landscape change. Society and Natural Resources 18:625-641.

Doak, S. C., and J. Kusel. 1996. Well-being in forest-dependent communities. Part II: A social assessment focus. Pages 375402 in Sierra Nevada Ecosystem Project. Final Report to Congress: Assessment and Scientific Basis for Management Options. Volume 2. Centers for Water and Wildland Resources, University of California, Davis, California, USA.

Donoghue, E. M., and V. E. Sturtevant. 2007. Social science constructs in ecosystem assessments: revisiting community capacity and community resiliency. Society and Natural Resources 20:899-912.

Donoghue, E. M., and V. E. Sturtevant, editors. 2008. Forest community connections: implications for research, management, and governance. Resources for the Future Press, Washington, D.C., USA.

Doyle, M., and C. A. Drew, editors. 2008. Large-scale ecosystem restoration: five case studies from the United States. Island Press, Washington, D.C., USA.

Eisenhauer, B. W., R. S. Krannich, and D. J. Blahna. 2000. Attachments to special places on public lands: an analysis of activities, meanings, and community connections. Society and Natural Resources 13:421-441.

Ellickson, R. C. 1991. Order without law: how neighbors settle disputes. Harvard University Press, Cambridge, Massachusetts, USA.

Endter-Wada, J., and D. J. Blahna. 2004. Linkages to the land: a framework for social assessment and impact analysis on public lands. Unpublished paper presented at the Tenth International Symposium on Society and Resource Management, Keystone, Colorado, June 2004.

Endter-Wada, J., D. Blahna, R. Krannich, and M. Brunson. 1998. A framework for understanding social science contributions to ecosystem management. Ecological Applications 8:891-904.

Endter-Wada, J., and R. J. Lilieholm, editors. 1995. Conflicts in natural resources management: integrating social and ecological concerns. Natural Resources and Environmental Issues. Volume 3. College of Natural Resources, Utah State University, Logan, Utah, USA.

Endter-Wada, J., T. Selfa, and L. Welsh. 2009. Hydrologic interdependencies and human cooperation: the process of adapting to droughts. Weather, Climate and Society 1:54-70.

Fairfax, S. K., L. P. Fortmann, A. Hawkins, L. Huntsinger, N. L. Peluso, and S. A. Wolf. 1999. The federal forests are not what they seem: formal and informal claims to federal lands. Ecology Law Quarterly 25:630-648.
Fairfax, S. K., L. Gwin, M. A. King, L. Raymond, and L. A. Watt. 2005. Buying nature: the limits of land acquisition as a conservation strategy, 1780-2004. MIT Press, Cambridge, Massachusetts, USA.

FEMAT [Forest Ecosystem Management Assessment Team]. 1993. Forest ecosystem management: an ecological, economic, and social assessment. Joint publication of: USDA Forest Service; United States Department of Commerce, National Oceanic and Atmospheric Administration and National Marine Fisheries Service; United States Department of the Interior, Bureau of Land Management; Fish and Wildlife Service, and National Park Service; and United States Environmental Protection Agency, Washington, D.C., USA.

Flora, C. B., J. L. Flora, and S. Fey. 2004. Rural communities: legacy and change. Second edition. Westview Press, Boulder, Colorado, USA.

Fortmann, L. 1990. Locality and custom: non-aboriginal claims to customary usufructuary rights as a source of rural protest. Journal of Rural Studies 6:195-208.

Fretwell, H. L. 2009. Who is minding the federal estate? Political management of America's public lands. Lexington Books (Division of Rowman and Littlefield Publishing Group), Lanham, Maryland, USA.

Freyfogle, E. 2003. The land we share: private property and the common good. Island Press, Washington, D.C., USA.

Freyfogle, E. 2007. On private property: finding common ground on the ownership of land. Beacon Press, Boston, Massachusetts, USA.

Gates, P. W. 1968. History of public land law development. U.S. Government Printing Office, Washington, D.C., USA.

Gates, P. W. 1979. Public land policies: management and disposal. Arno Press, New York, New York, USA.

Geisler, C. C. 1993. "Rethinking SIA: why ex ante research isn't enough." Society and Natural Resources 6:327-338.

Gilmore, D. W. 1997. Ecosystem management: a needs driven, resource use philosophy. Forestry Chronicle 73:560-564.

Gray, G. J., M. J. Enzer, and J. Kusel, editors. 2001. Understanding community-based forest ecosystem management. Forest Products Press as imprint of Haworth Press, Binghamton, New York, USA.

Grumbine, R. E. 1994. What is ecosystem management? Conservation Biology 8:27-38.

Gunderson, L. H., and C. S. Holling. 2001. Panarchy: understanding transformations in human and natural systems. Island Press, Washington, D.C., USA.

Hanna, S., C. Folke, and K.-G. Mäler, editors. 1996. Rights to natures: ecological, economic, cultural, and political principles of institutions for the environment. Island Press, Washington, D.C., USA.

Harris, C. C., W. J. McLaughlin, and G. Brown. 1998. Rural communities in the interior Columbia basin: How resilient are they? Journal of Forestry 96(3):11-15.

Harris, C. C., W. J. McLaughlin, G. Brown, and D. Becker. 2000. Rural communities in the inland northwest: an assessment of small rural communities in the Interior and Upper Columbia River Basins. General Technical Report PNW-GTR-477. Pacific Northwest Research Station, USDA Forest Service, Portland, Oregon, USA.

Heinz Center for Science, Economics and the Environment. 2008. The state of the nation's ecosystems 2008: measuring the land, waters, and living resources of the United States. Island Press, Washington, D.C., USA.

Hobbs, R. J., and K. N. Suding, editors. 2009. New models of ecosystem dynamics and restoration. Island Press, Washington, D.C., USA.

Holling, C. S., editor. 2005. Adaptive environmental assessment and management. Blackburn Press, Caldwell, New Jersey, USA. 
IOCGP [Interorganizational Committee on Principles and Guidelines for Social Impact Assessment]. 2003. Principles and guidelines for social impact assessment in the United States. Impact Assessment and Project Appraisal 21:231-250.

Keiter, R. B. 2003. Keeping faith with nature: ecosystems, democracy, and America's public lands. Yale University Press, New Haven, Connecticut, USA.

Keough, H., and D. J. Blahna. 2006. Achieving integrative, collaborative ecosystem management. Conservation Biology 20:1373-1382.

Kohm, K. A., and J. F. Franklin, editors. 1997. Creating a forestry for the 21st century: the science of ecosystem management. Island Press, Washington, D.C., USA.

Kruger, L. E., T. E. Hall, and M. Stiefel, technical editors. 2008. Understanding concepts of place in recreation research and management. General Technical Report PNW-GTR744. Pacific Northwest Research Station, USDA Forest Service, Portland, Oregon, USA.

Kusel, J. 2001. Assessing well-being in forest dependent communities. 2001. Pages 359-384 in G. J. Gray, M. J. Enzer, and J. Kusel, editors. Understanding communitybased forest ecosystem management. Forest Products Press as imprint of Haworth Press, Binghamton, New York, USA.

Kusel, J. 2003. Assessing well-being in forest dependent communities. Pages 81-102 in L. E. Kruger, technical editor. Understanding community-forest relations. General Technical Report PNW-GTR-566. Pacific Northwest Research Station, USDA Forest Service, Portland, Oregon, USA.

Kusel, J., and E. Adler. 2003. Forest communities, community forests. Rowman and Littlefield Publishers, Lanham, Maryland, USA.

Lachapelle, P., S. F. McCool, and M. E. Patterson. 2003. Barriers to resource planning in a "messy" world. Society and Natural Resources 16:473-490.

Layzer, J. A. 2008. Natural experiments: ecosystem-based management and the environment. MIT Press, Cambridge, Massachusetts, USA.

Leigh, R. 2003. Private rights in public resources: equity and property allocation in market-based environmental policy. Resources for the Future Press, Washington, D.C., USA.

Lilieholm, R. J., M. E. Tessema, D. J. Blahna, and L. E. Kruger. 2008. Using secondary data to estimate communityresource linkages in Utah's Grand Staircase-Escalante National Monument. Pages 424-435 in Proceedings of the 2006 GSENM Science Symposium, Southern Utah University, Sept. 12-14. Bureau of Land Management, U.S. Department of the Interior, Washington, D.C., USA.

Liu, J., et al. 2007a. Complexity of coupled human and natural systems. Science 317:1513-1516.

Liu, J., et al. 2007b. Coupled human and natural systems. AMBIO 36:639-649.

March, J. G. 1994. A primer on decision making: how decisions happen. Free Press, New York, New York, USA.

McDonnell, M. J., and S. T. A. Pickett, editors. 1997. Humans as components of ecosystems: the ecology of subtle human effects and populated areas. Springer-Verlag, New York, New York, USA.

McLain, R. J., E. M. Donoghue, J. Kusel, L. Buttoph, and S. Charnley. 2008. Multiscale socioeconomic assessment across large ecosystems: Lessons from practice. Society and Natural Resources 21:719-728.

McKinney, M., and W. Harmon. 2004. The western confluence: a guide to governing natural resources. Island Press, Washington, D.C., USA.

McLeod, K., and H. Leslie, editors. 2009. Ecosystem-based management for the oceans. Island Press, Washington, D.C., USA.
Meffe, G., L. Nielsen, R. L. Knight, and D. Schenborn. 2002. Ecosystem management: adaptive, community-based conservation. Island Press, Washington, D.C., USA.

Mekbeb, E. T., R. J. Lilieholm, D. J. Blahna, and L. E. Kruger. 2009. Resource use, dependence, and vulnerability: Community-resource linkages on Alaska's Tongass National Forest. WIT Transactions on Ecology and the Environment 122:263-272.

Moran, E. F., and E. Ostrom. 2005. Seeing the forests and the trees: human-environment interactions in forest ecosystems. MIT Press, Cambridge, Massachusetts, USA.

Nie, M. 2009. The governance of western public lands: mapping its present and future. University Press of Kansas, Lawrence, Kansas, USA.

Norton, B. G. 2005. Sustainability: a philosophy of adaptive ecosystem management. University of Chicago Press, Chicago, Illinois, USA.

Ostrom, E. 1990. Governing the commons: the evolution of institutions for collective action. Cambridge University Press, Cambridge, UK.

Ostrom, E. 2005. Understanding institutional diversity. Princeton University Press, Princeton, New Jersey, USA.

Ostrom, E., and E. Schlager. 1992. Property-rights regimes and natural resources: a conceptual analysis. Land Economics 68:249-262.

Ostrom, E., and E. Schlager. 1996. The formation of property rights. Pages 127-156 in S. S. Hanna, C. Folke, and K.-G. Mäler, editors. Rights to nature: ecological, economic, cultural, and political principles of institutions for the environment. Island Press, Washington, D.C., USA.

Pierson, P. 2004. Politics in time: history, institutions, and social analysis. Princeton University Press, Princeton, New Jersey, USA.

Ribot, J. C., and N. L. Peluso. 2003. A theory of access. Rural Sociology 68:153-181.

Sala, O. E., R. B. Jackson, H. A. Mooney, and R. W. Howarth, editors. 2000. Methods in ecosystem science. Springer-Verlag, New York, New York, USA.

Schneider, A. L., and H. Ingram. 1997. Policy design for democracy. University Press of Kansas, Lawrence, Kansas, USA.

Selfa, T., and J. Endter-Wada. 2008. The politics of community-based conservation in natural resource management: a focus for international comparative analysis. Environment and Planning A 40:948-965.

Senge, P. M. 1990. The fifth discipline: the art and practice of the learning organization. Currency Doubleday, New York, New York, USA.

Stankey, G. H., R. N. Clark, and B. T. Bormann. 2005. Adaptive management of natural resources: theory, concepts, and management institutions. General Technical Report PNW-GTR-654. Pacific Northwest Research Station, USDA Forest Service, Portland, Oregon, USA.

Taylor, C. N., C. H. Bryan, and C. G. Goodrich. 2004. Social assessment: theory, process and techniques. Social Ecology Press, Middleton, Wisconsin, USA.

Thomas, J. W. 1994. Forest ecosystem management assessment team: objectives, process and options. Journal of Forestry 92:12-17. 19.

Thorpe, J. H., M. C. Thomas, and M. D. Delong. 2008. The riverine ecosystem synthesis: toward conceptual cohesiveness in river science. Elsevier Academic Press, London, UK.

Tsournos, P., and R. W. Haynes. 2004. An assessment of growth and development paths for southeast Alaska. General Technical Report PNW-GTR-620. USDA Forest Service, Pacific Northwest Research Station, Portland, Oregon, USA. Utah GOPB [Governor's Office of Planning and Budget]. 2003. Dixie, Fishlake, and Manti-La Sal National Forests, forest 
plan revision, social and economic assessment. Utah GOPB, Salt Lake City, Utah, USA. 〈http://www.planning.utah.gov/ usfs.htm $\rangle$

Walker, G. B., and S. E. Daniels. 1996. The Clinton Administration, the northwest forest conference, and managing conflict: when talk and structure collide. Society and Natural Resources 9:77-91.

Waring, R. H., and S. W. Running. 2007. Forest ecosystems: analysis at multiple scales, third edition. Elsevier Academic Press, London, UK.

Wilkinson, C. F. 1992. Crossing the next meridian: land, water and the future of the American West. Island Press, Washington, D.C., USA.

Williams, D. R., M. E. Patterson, J. W. Roggenbuck, and A. E. Watson. 1992. Beyond the commodity metaphor: examining emotional and symbolic attachments to place. Leisure Sciences 14:29-46.

Williams, P. B. 2006. An interdisciplinary and multi-theoretic strategy for bridging theory and practice of collaborative public land management. Dissertation. Utah State University, Logan, Utah, USA.

Williams, P. B., and D. J. Blahna. 2007. Public communication and participation strategies relevant to wildland recreation management and research. Pages 67-80 in L. E. Kruger, R. Mazza, and K. Lawrence, editors. Proceedings of the National Workshop on Recreation Research and Management. General Technical Report PNW-GTR-698. Pacific Northwest Research Station, USDA Forest Service, Portland, Oregon, USA.

Wondolleck, J. M., and S. L. Yaffee. 2000. Making collaboration work: lessons from innovation in natural resource management. Island Press, Washington, D.C., USA.

Yaffee, S. L., A. F. Phillips, I. C. Frents, P. W. Hardy, S. M. Maleki, and B. E. Thorpe. 1996. Ecosystem management in the United States: an assessment of current experience. Island Press, Washington, D.C., USA.

Young, R. A., and R. L. Giese. 2003. Introduction to forest ecosystem science and management, third edition. John Wiley and Sons, New York, New York, USA. 